\title{
STUDY OF CEPHALIC INDEX AMONG THE STUDENTS OF MARATHWADA
} REGION

\author{
Syed Imran Sultan ${ }^{* 1}$, Vishal M. Tekale ${ }^{1}$, C. V. Diwan ${ }^{2}$.
}

${ }^{{ }_{1}}$ Assistant Professor, Department of Anatomy, Shankarrao Chavan Government Medical College Nanded, Maharashtra, India.

${ }^{2}$ Professor and Head, Department of Anatomy, Shankarrao Chavan Government Medical College Nanded, Maharashtra, India.

\section{ABSTRACT}

Background: Cephalic Index is a useful anthropological tool for analysis of racial differences in a population and also to ascertain sexual dimorphism. Comparison of changes in cephalic index between parents, offspring's and siblings can give information about the genetic transmission of the inherited characters.

Materials and Methods: This study was carried on 200 medical students (100 male and 100 female students) of Marathwada region. The Cephalic Index was measured using Hrdlicka's Method.

Result: Mean Cephalic Index for male student was $79.12 \pm 6.02$ and for female student was $78.67 \pm 6.45$. Mean cephalic index irrespective of gender was found to be $78.89 \pm 6.23$.

Conclusion: In Marathwada region of Maharashtra, there is a pre dominance of mesocephalic head. The data presented in the present study can be useful for comparison among the regional differences and in forensic medicine and anthropology for comparative and evolutionary studies.

KEY WORDS: cephalic index, head length, head breadth, anthropometry, marathwada region.

Address for Correspondence: Dr. Syed Imran Sultan, Department of Anatomy, Shankarrao Chavan Government Medical College Nanded, Maharashtra, India, E-Mail: drsyedimran86@gmail.com

\begin{tabular}{|l|l|}
\hline \multicolumn{3}{|c|}{ Access this Article online } \\
\hline Quick Response code & $\begin{array}{l}\text { Web site: International Journal of Anatomy and Research } \\
\text { ISSN 2321-4287 } \\
\text { www.ijmhr.org/ijar.htm }\end{array}$ \\
\cline { 2 - 3 } & \multicolumn{2}{|c|}{$\begin{array}{l}\text { Accepted: 18 Jun } 2017 \\
\text { DoI: 10.16965/ijar.2017.254 }\end{array}$} & $\begin{array}{l}\text { Received: 12 May 2017 } \\
\text { Revised: None }\end{array}$ & $\begin{array}{l}\text { Published (O): 31 Jul } 2017 \\
\text { Published (P): 31 Jul } 2017\end{array}$ \\
\hline
\end{tabular}

\section{INTRODUCTION}

Anthropometric measurements are important tool for comparison and to achieve a more objective racial assessment. Standardised cephalometric records enable diagnostic comparison between patients and the normal population [1].

Cephalic Index is a useful anthropological tool for analysis of racial differences in a population and also to ascertain sexual dimorphism. Comparison of changes in cephalic index between parents, offspring's and siblings can give information about the genetic transmission of the inherited characters [2].

The Cephalometric results can also be of great assistance while evaluating patients in various fields of medicine like Medical Imaging, Paediatrics, Craniofacial Surgery and also for studying growth trends in various castes/races within a defined geographic zone. Anthropometric study of head is useful in designing various equipment's of head and face like helmets, head phones, goggles, etc. by formulating standard sizes [3].

In the present study we calculated the cephalic index of the medical students of Marathwada 
region of Maharashtra and compared with previous studies. Anthropometric measurements are important tool for comparison and to achieve a more objective racial assessment. Standardised cephalometric records enable diagnostic comparison between patients and the normal population [1].

Cephalic Index is a useful anthropological tool for analysis of racial differences in a population and also to ascertain sexual dimorphism. Comparison of changes in cephalic index between parents, offspring's and siblings can give information about the genetic transmission of the inherited characters [2].

The Cephalometric results can also be of great assistance while evaluating patients in various fields of medicine like Medical Imaging, Paediatrics, Craniofacial Surgery and also for studying growth trends in various castes/races within a defined geographic zone. Anthropometric study of head is useful in designing various equipment's of head and face like helmets, head phones, goggles, etc. by formulating standard sizes [3].

In the present study we calculated the cephalic index of the medical students of Marathwada region of Maharashtra and compared with previous studies.

\section{MATERIALS AND METHODS}

The present study was carried out with 200 medical students (100 male and 100 female students) of Shankarrao Chavan Government Medical College, Nanded, Marathwada region, Maharashtra. Medical students were selected because of the easy availability. The age of the students ranged from $18-23$ years. The written consent was obtained from each and every student before taking the measurements. Any student having physical deformity, craniofacial trauma were excluded from the study.

The Hrdlicka's method was used for assessing the Cephalic Index [4]. Following anatomical landmarks were marked and defined:

Glabella: A point above the nasal root between the eyebrows and intersected by mid-sagittal plane.

Inion: The distal most point placed on the external occipital protuberance in the mid- sagittal plane.

Euryon: The lateral most point placed on the side of the head.

All the measurements were taken with the subject sitting in chair, in relaxed condition \& the head in the anatomical position.

The maximum head length was measured as the maximum antero-posterior diameter by spreading callipers from glabella to inion.

The maximum head breadth was measured as the maximum transverse diameter between two euryons using spreading callipers.

All measurements were taken in centimetres and to an accuracy of 0.10 . The cephalic indices were calculated by multiplying the head breadth with 100 and dividing it with the head length.

Cephalic Index = Maximum head Breadth $\times 100$ Maximum head Length

Depending upon this index the types of head shapes were classified as follows [5]:

\begin{tabular}{|c|c|c|}
\hline Sr. No & Type of Skull & $\begin{array}{c}\text { Range of Cephalic } \\
\text { Index }\end{array}$ \\
\hline 1 & Dolichocephalic & $70-74.9$ \\
\hline 2 & Mesocephalic & $75-79.9$ \\
\hline 3 & Brachycephalic & $80-84.9$ \\
\hline 4 & Hyperbrachycephalic & $85-89.9$ \\
\hline
\end{tabular}

All the data were analysed using Microsoft Excel and SPSS software by using unpaired ' $\mathrm{t}$ ' test. Mean and Standard deviation were calculated.

\section{RESULTS}

The mean of Maximum head length in Male students is $17.88 \pm 1.03$ and in female is 17.46 \pm 1.07 . The average of maximum head length in male and female students taken together is $17.67 \pm 1.07$. (Table 1 )

Table 1: Gender wise distribution of Maximum Head Length in study sample.

\begin{tabular}{|c|c|c|c|}
\hline Sr. No. & Sex & $\begin{array}{c}\text { No. of } \\
\text { subject }\end{array}$ & $\begin{array}{c}\text { Maximum Head } \\
\text { Length } \\
\text { (Mean } \pm \text { SD) }\end{array}$ \\
\hline 1 & Male & 100 & $17.88 \pm 1.03$ \\
\hline $\mathbf{2}$ & Female & 100 & $17.46 \pm 1.07$ \\
\hline 3 & Male + Female & 200 & $17.67 \pm 1.07$ \\
\hline
\end{tabular}

The mean of Maximum head breadth in Male students is $14.10 \pm 0.73$ and in female is 13.69 \pm 0.80 . The average of maximum head breadth 
in male and female students taken together is $13.89+0.79$. (Table 2)

Table 2: Gender wise distribution of Maximum Head Breadth in study sample.

\begin{tabular}{|c|c|c|c|}
\hline Sr. No. & Sex & $\begin{array}{c}\text { No. of } \\
\text { subject }\end{array}$ & $\begin{array}{c}\text { Maximum Head } \\
\text { Breadth } \\
\text { (Mean } \pm \text { SD) }\end{array}$ \\
\hline $\mathbf{1}$ & Male & 100 & $14.10 \pm 0.73$ \\
\hline $\mathbf{2}$ & Female & 100 & $13.69 \pm 0.80$ \\
\hline $\mathbf{3}$ & Male + Female & 200 & $13.89 \pm 0.79$ \\
\hline
\end{tabular}

The mean of Cephalic Index in Male students is $79.12 \pm 6.02$ and in female is $78.67 \pm 6.45$. The average of Cephalic Index in male and female students taken together is $78.89 \pm 6.23$. The Mean Cephalic Index of students of Marathwada region in our study lies in mesocephalic range.(Table 3)

Table 3: Gender wise distribution Cephalic Index in study sample.

\begin{tabular}{|c|c|c|c|}
\hline Sr. No. & Sex & $\begin{array}{c}\text { No. of } \\
\text { subject }\end{array}$ & $\begin{array}{c}\text { Cephalic Index } \\
\text { (Mean } \pm \text { SD) }\end{array}$ \\
\hline 1 & Male & 100 & $79.12 \pm 6.02$ \\
\hline 2 & Female & 100 & $78.67 \pm 6.45$ \\
\hline 3 & Male + Female & 200 & $78.89 \pm 6.23$ \\
\hline
\end{tabular}

In the present study, we found that 43 students (21.5\%) shows dolichocephalic range, 79 students (39.5\%) shows mesocephalic range, 47 students (23.5\%) shows brachycephalic range and 31 students ( $15.5 \%$ ) shows hyperbrac hycepahlic range. (Table 4, Graph 1).

Table 4: Gender wise classification of Head shape in study sample.

\begin{tabular}{|c|c|c|c|}
\hline Type of Head Shape & $\begin{array}{c}\text { Male } \\
\text { (100 students) }\end{array}$ & $\begin{array}{c}\text { Female } \\
\text { (100 students) }\end{array}$ & $\begin{array}{c}\text { Male + Female } \\
\text { (200 students) }\end{array}$ \\
\hline Dolichocephalic & 19 & 24 & $43(21.5 \%)$ \\
\hline Mesocephalic & 41 & 38 & $79(39.5 \%)$ \\
\hline Brachycephalic & 25 & 22 & $47(23.5 \%)$ \\
\hline Hyperbrachycephalic & 15 & 16 & $31(15.5 \%)$ \\
\hline
\end{tabular}

Graph 1: Gender wise classification of Head shape in study sample.

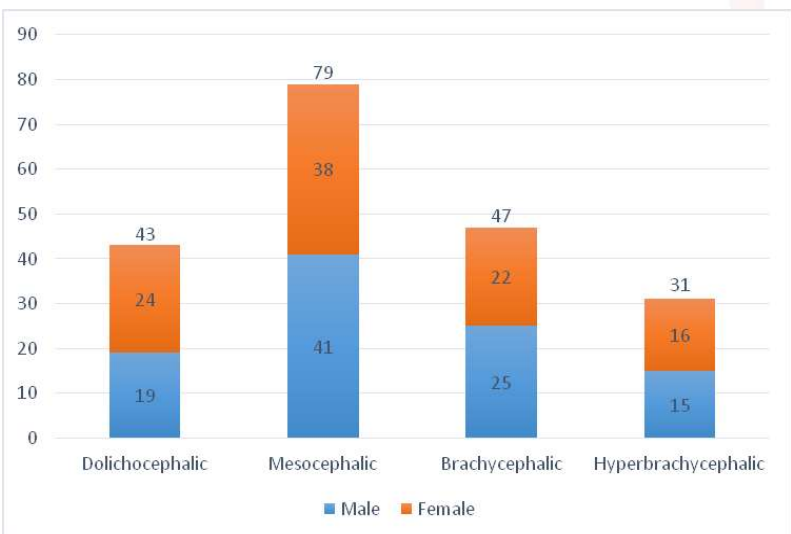

\section{DISCUSSION}

The variations in the cephalic indices between and within populations have been attributed to a complex interaction between genetic and environmental factors [6].

\begin{tabular}{|c|l|c|c|c|c|}
\hline \multirow{2}{*}{ Sr. } & \multirow{2}{*}{ Name of Author } & \multirow{2}{*}{ Population studied } & \multicolumn{3}{|c|}{ Mean Cephali Index } \\
\cline { 4 - 6 } No & & & Male & Female & Male + Female \\
\hline 1 & Anupama Mahajan et al (2009) [7] & Punjab & 81.34 & 85.75 & 85.53 \\
\hline 2 & Vishal Salve et al (2011) [8] & Andhra region & 75.68 & 78.2 & 76.94 \\
\hline 3 & Vaishali Kiran et al (2012) [9] & Manipal & 77.92 & 80.85 & - \\
\hline 4 & Swapnil Khair et al (2013) [3] & Mumbai & 81.28 & 75.22 & 78.48 \\
\hline 5 & Kanan Uttekar et al (2013) [10] & South Gujrat & 80.88 & 82.48 & 81 \\
\hline 6 & Shema Nair et al (2014) [11] & Central India & 81.24 & 80.31 & 81.21 \\
\hline 7 & Meghna Mishra et al (2014) [12] & Madhya Pradesh & 75.84 & 79.05 & 77.79 \\
\hline 8 & Sunita Patro et al (2014) [13] & South Odisha & 77.28 & 78.38 & 77.75 \\
\hline 9 & K. Lakshmi Kumari et al (2015) [14] & Vishakhapatnam & 80.21 & 79.25 & - \\
\hline 10 & Present Study (2017) & Marathwada & 79.12 & 78.67 & 78.89 \\
\hline
\end{tabular}

In the present study, the mean cephalic index in males (79.12) is higher than the studies of Vishal Salve et al (75.68), Vaishali kiran et al (77.92), Meghna Mishra et al (75.84) and Sunita Patro et al (77.28) which shows mesocephalic range in the above studies. Whereas it is lower than the studies of Anupama Mahajn et al (81.34), Swapnil khair et al (81.28), Kanan Uttekar et al (80.88), Shema Nair et al (81.24) and K. Lakshmi kumara et al (80.21) which shows brachycephalic range.

In the present study, the mean cephalic index in females (78.67) is higher than the studies of Vishal Salve et al (78.20), Swapnil khair et al (75.22) and Sunita Patro et al (78.38) which shows mesocephalic range in the above studies. Whereas it is lower than the studies of Anupama Mahajan et al (85.75), Vaishali Kiran et al (80.85), Kanan Uttekar et al (82.48), Shema Nair et al (80.31) Meghna Mishra et al (79.05) and K. Lakshmi Kumara et al (79.25), which shows brachycephalic range in studies of Anupama Mahajan et al, Vaishali Kiran et al, Kanan Uttekar et al and Shema Nair et al.

In the present study the Mean Cephalic Index in overall study sample (78.89) is higher than the studies of Vishal Salve et al (76.94), Swapnil Khair et al (78.48), Meghna Mishra et al (77.79) and Sunita Patro et al (77.75) which shows the mesocephalic range in the above studies. Whereas, it is lower than Anupama Mahajan et al (85.53), Kanan Uttekar et al (81.00) and Shema Nair et al (81.21) which shows the brachycephalic range. 
The variations of head shape may be due to hereditary factor or environmental which may act as secondary effect [15]. The kind of diet taken could also play a role in influencing the dominant head shape. Head shapes can also change from one generation to the other ${ }^{16}$.

\section{CONCLUSION}

To conclude in Marathwada region of Maharashtra, there is a pre dominance of mesocephalic head, with mean cephalic index of $78.89 \pm 6.23$ $(79.12 \pm 6.02$ in males and $78.67 \pm 6.45$ in females). The data presented in the present study can be useful for comparison among the regional differences and in forensic medicine and anthropology for comparative and evolutionary studies.

\section{Conflicts of Interests: None}

\section{REFERENCES}

[1]. Rabey GP. Craniofacial morphanalysis. Proc R Soc Med 1971;64:103-11.

[2]. Shah GV, Jadhav HR.The study of cephalic index in students of Gujrat. J Anat Soc India. 2004;53(1):112.

[3]. Swapnali Khair et al. Study of Cephalic Index among the students of Mumbai region. Ind J of Applied Research. 2013;11(3):64-66.

[4]. Hrdlika Practical Anthropometry. 4th Edition, Philadelphia. The Wistar institute of Anatomy and Biology, 1952:87-89.

[5]. William P, Dyson M, DussaakJ E, Bannister LH, Berry MM, Collins P, Ferguson MWJ. Gray's Anatomy. In: Skeletal system, 38th Edn. 1995 Elbs with Churchil Livingston, London, p 607-612.

[6]. Kasai K, Richards LC and Brown T.Comparative study of craniofacial morphology in Japanese and Australian aboriginal population. Hum Biol 1993;65(5):821-34.
[7]. M. Anupama, K. B. Singh, Seema, and B. A. P. Singh. The study of cephalic index in Punjabi students. Journal of Punjab Academy of Forensic Medicine \& Toxicology 2009;9(2):66-70.

[8]. Salve VM,Thota NR, Patibandla A. The study of cephalic index of Andhra region (India). Asian Journal of Medical Sciences 2011;2:53-55.

[9]. Yagain, V. K.; Pai, S. R.; Kalthur, S. G.; Chethan, P. \& Hemalatha, I. Estudio del índice cefálico en estudiantes Indios. Int. J. Morphol., 2012;30(1):125129.

[10]. Kanan Uttekar et al, Study of Cephalic Index in South Gujarat. International Journal of Recent Trends in Science And Technology 2013;8(2):87-89.

[11]. Shema K. Nair, Vaibhav P. Anjankar, Sandeep Singh, Maninder Bindra, D. K. Satpathy. The Study of Cephalic Index of Medical Students of Central India. Asian Journal of Biomedical and Pharmaceutical Sciences 2014;04(28):48-50.

[12]. Mishra M, Tiwari A, Naik DC. Study of cephalic index in Vindhya region of Madhya Pradesh. Int J Med Sci Public Health 2014;3:1464-1465.

[13]. Patro S, Sahu R, Rath S. Study of cephalic index in Southern Odisha population. J. Dental and Med. Sci. 2014;13:41-4.

[14].Lakshmi Kumari K, Vijaya Babu PVSS, Kusuma Kumari $P$, Nagamani M. A study of cephalic index and facial index in Visakhapatnam, Andhra Pradesh, India. Int J Res Med Sci 2015;3:656-8.

[15]. Golalipour, M. J.; Jahanshahi, M. \& Haidari, K. Morphological evaluation of head in Turkman males in Gorgan-North of Iran. Int. J. Morphol., 2007;25:99102.

[16]. Heravi, F. \& Zieaee, H. Assessing the importance of cephalic and facial indices in a group of 12 year old boys in Mashhad. Beheshti Univ. Dent. J., 2002;20:119-24.

\section{How to cite this article:}

Syed Imran Sultan, Vishal M. Tekale, C. V. Diwan. STUDY OF CEPHALIC INDEX AMONG THE STUDENTS OF MARATHWADA REGION. Int J Anat Res 2017;5(3.1):4078-4081. DOI: 10.16965/ ijar.2017.254 